\title{
Nutraceutical-based Integrative Medicine: Adopting a Mediterranean Diet Pyramid for Attaining Healthy Ageing in Veterans with Disabilities
}

\author{
Mario Ciccotti ${ }^{\mathrm{a}, \mathrm{b}}$, Anna Raguzzini $^{\mathrm{c}}$, Tommaso Sciarra $^{\mathrm{a}}$, Giovina Catasta ${ }^{\mathrm{c}}$, Paola Aiello ${ }^{\mathrm{c}}$, Cosimo Buccolieri ${ }^{\mathrm{a}}$, \\ Raffaella Reggi ${ }^{\mathrm{b}, \mathrm{d}}$, Maura Palmery ${ }^{\mathrm{b}} \dot{\dagger}$, Florigio Lista ${ }^{\mathrm{e} \dagger}$ and Ilaria Peluso ${ }^{\mathrm{c}} *$ '
}

\begin{abstract}
${ }^{a}$ Joint Veteran Center, ${ }^{e}$ Scientific Department, Army Medical Center, Rome, Italy; ${ }^{b}$ Department of Physiology and Pharmacology " $V$. Erspamer", La Sapienza University of Rome, Rome, Italy, ${ }^{c}$ Research Centre for Food and Nutrition, Council for Agricultural Research and Economics (CREA-AN), Rome, Italy, ${ }^{d}$ Scientific Technical Secretariat of the Lazio Ethics Committee 2, ${ }^{e}$ Scientific Department, Army Medical Center, Rome, Italy
\end{abstract}

\begin{abstract}
Veterans with disability represent a big burden worldwide and often require long-term rehabilitation. Unhealthy dietary and lifestyle habits, including smoke and alcohol abuse, are common in veterans. In the context of integrative medicine approaches, the "complementary and alternative medicine" has been suggested for the management of chronic diseases. However, the potential risk of interaction between herbal products, dietary supplements and drugs must be considered in veterans. The Mediterranean diet has been suggested as a natural, non-pharmacological nutraceutical for healthy ageing. Although there is a broad consensus on the positive effect of plant foods consumption, the presence of glucosinolates, flavonoids and furanocoumarins in some plant foods and beverages must be taken into consideration owing to their potential interfering with drugs metabolism and bioavailability. Albeit seasonality could ensure the maintenance of the single dose of phytochemical below that at which adverse effects in some individuals genetically predisposed or unpleasant drug interactions in diseased subjects can occur, a personalized nutrition is recommended in veterans who are under treatment for comorbidities. Furthermore, sports practice can lead veterans with motor disabilities and mental impairments to excel in some disciplines, giving rise to the phenomenon of the Paralympics and the development of "recreational therapy". Moreover, outdoor lifestyle, through vitamin D synthesis, and conviviality, improving socialization, could account for the Mediterranean lifestyle health benefits. In this work, we propose for veterans a Mediterranean Pyramid, which could be the basis for integrative medicine for veterans with disabilities, patient-centered approaches and interprofessional (including physical medicine and rehabilitation clinicians, pharmacists and nutritionists) interventions.
\end{abstract}

Keywords: Post-traumatic stress disorder, spinal cord injury, rehabilitation, cognition, energy balance, water balance.

\section{INTRODUCTION}

Veterans with disability represent a big burden worldwide, both in developing and in developed countries. Armed conflict generates disabilities due to injuries and/or trauma. For veterans incurring such injuries, the situation is often exacerbated by delays in obtaining emergency health care and long-term rehabilitation. The Us Bureau of Census [1] estimated that in $201428.8 \%$ of veterans (18 years and older) had any type of disability, as defined by the American Community Survey (ACS), and $19.6 \%$ of veterans had a Veteran Affair (VA) service-connected disability rating. In particular, $8.6 \%$ of veterans had both a service-connected disability and an ACS-defined disability; service-connected disability in absence of ACS-defined disability was observed in $11 \%$ of veterans, while $20.2 \%$ of them had no service-connected disability but presented an ACS-defined disability.

Moreover, global ageing has a major influence on disability trends. Both physical disability [2] and psychological [2-5] illnesses, observed in veterans, are negatively associated with successful ageing [6]. Furthermore, subjective age perception is affected by post-traumatic stress disorder (PTSD) [7] and disability

*Address correspondence to these authors at the Research Centre for Food and Nutrition, Council for Agricultural Research and Economics (CREAAN), via Ardeatina 546, Rome, Italy; E-mails: ilaria.peluso@crea.gov.it; i.peluso@tiscali.it ; † co-corresponding: Florigio Lista. Scientific Department, Army Medical Center. Via Santo Stefano Rotondo 4, Roma 00184 Emaill: romano.lista@gmail.com ; Maura Palmery, Department of Physiology and Pharmacology "V. Erspamer", "Sapienza" University of Rome, P.le Aldo Moro 5, 00185 Rome, Italy maura.palmery@uniromal.it
[7]. For this reason, low perceived health and low quality of life are often reported by veterans $[8,9]$. In particular, chronic pain [10-12] and chronic fatigue syndrome [13] are common in veterans. Moreover, PTSD is also associated with both the decline in cognitive functioning [14], which is correlated with age and depression [15], and social anxiety disorder in veterans [16]. A meta-regression reported that soldiers and veterans with PTSD benefited less from psychotherapy than non-military subjects [17]. In addition to pharmacotherapy [18-20], meditation [21-23] and psychological programs [20, 24-29], complementary and alternative medicine (CAM), including acupuncture [21, 30], massage [31] and Yoga [32-36], have been suggested for the management of PTSD and chronic diseases in the context of integrative medicine approaches [37-39]. In general, sex, racial/ethnic, socioeconomic and cultural differences have been reported in the prevalence of CAM use [4042]. Acupuncture, massage, yoga, meditation and spiritual healing are preferentially chosen by women in veterans [43], and meditation and acupuncture are also common in active duty military members [44]. Moreover, CAM has been suggested for the management of chronic pain [32, 33, 45] and it is common among veterans with cancer [45]. A recent meta-analysis has not supported Yoga treatment for chronic pain and has reported limited evidence on the improvement of the quality of life and depression [46]. However, promising results on pain have been recently reported by the Restorative Exercise and Strength Training for Operational Resilience and Excellence (RESTORE) program (9-12 individual yoga sessions for 8 weeks) [47]. Furthermore, meditation programs $[22,23]$ and mindfulness-based interventions [27-29] have seemed promising for veterans with PTSD $[22,23,28]$ and for subjects with 
anxiety $[27,29,48]$ and depression [29], potentially reducing suicidal ideation in veterans [29]. PTSD and depression often cooccurred [49] and it has been suggested that depression could be an important factor in the relationship between PTSD and metabolic syndrome [50]. A retrospective study, by the examination of clinical records of Italian soldiers who were admitted during the World War I, confirmed that soldiers engaged in war are at higher risk of developing depression compared to non-deployed soldiers [51]. In Italy the so-called "reconstruction programs" addressed all aspects of rehabilitation (including physiotherapy, curative workshops and vocational therapy) [52]. On the other hand, it has been recently reported that, despite working as a peacekeeper which is associated with the exposure to acute and/or catastrophic events and chronic stressors, Italian peacekeeper soldiers exhibit lower levels of internalizing symptoms (i.e., PTSD, depression, general anxiety, obsessions, and somatization) and have higher levels of quality of life (i.e., higher life satisfaction and lower general stress), as compared to a control group [53]. In this context, in addition to the health property of the Mediterranean lifestyle, Mediterranean diet has been suggested as a natural, non-pharmacological nutraceutical for healthy ageing $[54,55]$ and metabolic syndrome prevention [56]. Therefore, according to the needs to strengthen and support research on disability, as reported by the World Health Organization [57], the evaluation of the effects of nutraceuticals, lifestyle interventions and environmental factors on military personnel affected by physical and psychological impairment is an interesting topic.

In this work, after discussing the pros and cons of nutraceuticals and supplements, we aim to evaluate the possible use of the Mediterranean pyramid as integrative medicine in veterans (Fig. 1).

\section{DIETARY SUPPLEMENTS AND NUTRACEUTICALS: FRIENDS OR FOES?}

Bodybuilding, energy and/or weight-loss supplements are used by military personnel [58], and herb and supplement use is common in general population [59], as well as in elderly subjects [60] and in veterans with cancer [45].

Belief in the health effects of nutraceuticals and supplements positively affects the attitude and consumption [61]. In particular, the attitude to use herbal remedies has been ascribed to different factors, including the conviction that they were natural [62] and the dissatisfaction with conventional treatments [63].

On the other hand, in veterans with mental illness, the relationship between CAM use and the perceived effectiveness of conventional treatments (drugs and psychotherapy) is still controversial $[64,65]$. However, data from a meta-analysis reported no differences between some CAM (including omega-3 fatty acids, Sadenosyl methionine and St. John's wort) and second-generation antidepressants in major depressive disorder [66].

Table 1 summarizes intervention studies [67-82] with supplements and nutraceuticals aimed to evaluate the effects of these treatments on mood, cognition and physical performance.

In the "VA homocysteine study" no effects on cognition were observed in chronic kidney disease (CKD) patients after folic acid, vitamin B6 and vitamin B12 supplementation, despite the reduction in homocysteine levels [67]. On the contrary, in the elderly [69, 70], mild cognitive impairment (MCI) patients [77] and subjects with

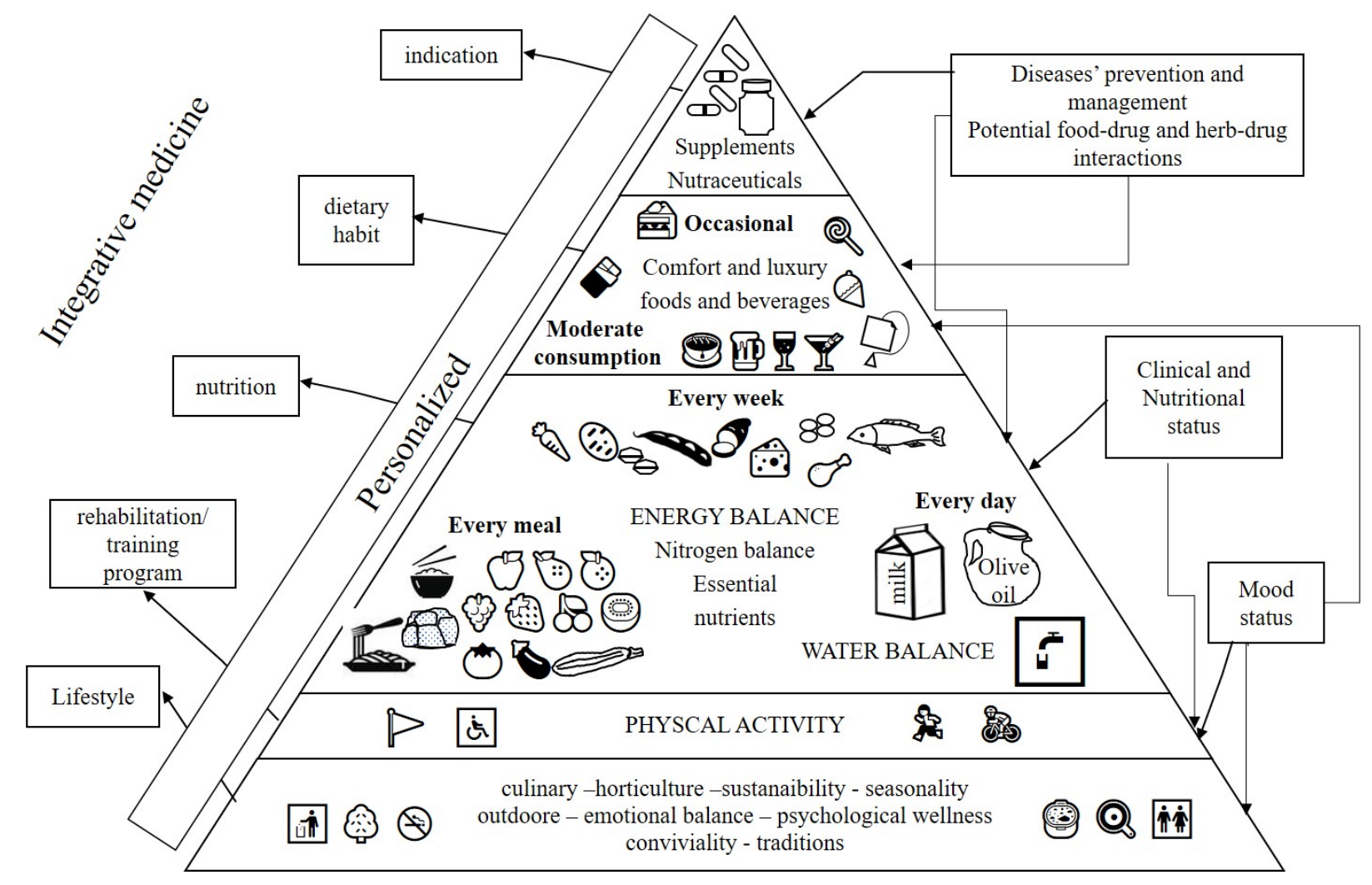

Fig. (1). Mediterranean pyramid for veterans.

Modified from the SENC http:/www.efesalud.com/estilos-de-vida-saludable-nuevas-recomendaciones-de-la-piramide-nutricional-senc-2015/ and the new Mediterranean diet Italian [152] Pyramids. 
Table 1. Intervention studies with supplements and nutraceuticals.

\begin{tabular}{|c|c|c|c|}
\hline Subjects & Treatment, duration & Outcomes & Refs. \\
\hline $\begin{array}{l}\text { CKD }(n=659) \text { treated with dialysis } \\
\text { and advanced CKD }(n=423) \text { (creatin- } \\
\text { ine clearance of } 30 \mathrm{~mL} / \mathrm{min} \text { or less). }\end{array}$ & $\begin{array}{l}\text { Multivitamin [folic acid }(40 \mathrm{mg})+\text { vitamin B6 }(100 \mathrm{mg})+\text { of } \\
\qquad \text { vitamin B12 }(2 \mathrm{mg})] \\
\text { or placebo, } 1 \text { year. }\end{array}$ & $\leftrightarrow$ Cognition & {$[67]$} \\
\hline Depression $(\mathrm{n}=57)$ & $\begin{array}{l}\text { R. rosea } \text { SHR-5 powdered extract ( } 340 \mathrm{mg} \text {; standardized to a } \\
\text { content of rosavin } 3.07 \% / \text { rhodioloside } 1.95 \% \text { ) } \\
\text { sertraline or placebo, } 12 \text { weeks }\end{array}$ & $\begin{aligned} \leftrightarrow & \text { versus placebo (less antidepres- } \\
& \text { sant effect versus sertraline) }\end{aligned}$ & [68] \\
\hline Elderly $(\mathrm{n}=101)$ & $\begin{array}{l}\text { Pycnogenol }(150 \mathrm{mg}) \text {, } \\
\text { or placebo, } 3 \text { months }\end{array}$ & $\uparrow$ Cognition & [69] \\
\hline Elderly $(\mathrm{n}=54)$ & $\begin{array}{l}\text { Bacopa monnieri whole plant standardized dry extract (300 } \\
\text { mg/day) or a placebo, } 12 \text { weeks. }\end{array}$ & $\uparrow$ Cognition & {$[70]$} \\
\hline Elderly $(\mathrm{n}=80)$ & $\begin{array}{c}\text { Centella asiatica extract }(250,500 \text { and } 750 \mathrm{mg}) \text {, } \\
\text { or placebo, } 90 \text { days. }\end{array}$ & $\uparrow$ Physical performance & {$[71]$} \\
\hline $\begin{array}{l}\text { Elderly undergoing major elective } \\
\text { operations requiring ICU }(n=325)\end{array}$ & $\begin{array}{c}\text { L-tryptophan ( } 1 \mathrm{~g} \text { orally three/day) } \\
\text { or placebo, after surgery and for up to } 3 \text { days postoperatively }\end{array}$ & $\begin{array}{l}\leftrightarrow \text { Incidence or duration of postop- } \\
\text { erative delirium }\end{array}$ & {$[72]$} \\
\hline GAD $(n=10)$ & Rhodiola rosea herbal extract ( $340 \mathrm{mg}), 10$ weeks & $\downarrow$ Anxiety & {$[73]$} \\
\hline GAD $(n=72)$ & $\begin{array}{c}\text { Manasamitra Vataka tablets (100 mg twice daily). } \\
\text { Manasamitra Vataka tablets }+ \text { Shirodhara (therapy involving } \\
\text { dripping of medicated oil [Brahmi tail] over the forehead) } \\
\text { treatment for the first } 7 \text { days. } \\
\text { or clonazepam, } 30 \text { days }\end{array}$ & $\downarrow$ Anxiety (all treatments) & {$[74]$} \\
\hline $\begin{array}{l}\text { GWI (disabling fatigue, widespread } \\
\text { pain, and cognitive dysfunction) }(\mathrm{n}= \\
\text { 25) }\end{array}$ & $\begin{array}{l}\text { L-carnosine (B-alanyl-L-histidine) }(500,1000, \text { and } 1500 \mathrm{mg} \\
\text { increasing at } 4 \text { weeks intervals) or placebo, } 12 \text { weeks }\end{array}$ & $\begin{array}{c}\uparrow \text { Cognition } \\
\leftrightarrow \text { Fatigue, pain, hyperalgesia }\end{array}$ & {$[75]$} \\
\hline $\operatorname{MCI}(n=95)$ & $\begin{array}{l}\text { Dangguijagyag-san (DJS, angelica and peony formula } 1.875 \mathrm{~g} \\
\text { twice/d), } 12 \text { weeks, follow-up } 1 \text { year }\end{array}$ & $\uparrow$ Cognition & [77] \\
\hline $\operatorname{MDD}(\mathrm{n}=92)$ & $\begin{array}{l}\text { Chlorella vulgaris extract (CVE) }(1800 \mathrm{mg} / \text { day; } \mathrm{n}=42) \text { or con- } \\
\text { tinued standard antidepressant therapy alone, } 6 \text { weeks. }\end{array}$ & $\downarrow$ Anxiety and Depression & [78] \\
\hline $\begin{array}{l}\text { Schizophrenia and tardive dyskinesia } \\
\qquad(\mathrm{n}=152)\end{array}$ & Ginkgo biloba extract (EGb) $240 \mathrm{mg} / \mathrm{d}, 12$ weeks or placebo & $\downarrow$ Tardive dyskinesia symptoms & [79] \\
\hline $\begin{array}{l}\text { Veterans (elderly) with baseline } \\
25(\mathrm{OH}) \mathrm{D} \leq 30 \mathrm{ng} / \mathrm{mL}(\mathrm{n}=130)\end{array}$ & Vitamin D 4,000 IU or placebo, 9 months & $\leftrightarrow$ Physical performance & {$[80]$} \\
\hline $\begin{array}{l}\text { Veterans with chronic pain and base- } \\
\text { line } 25(\mathrm{OH}) \mathrm{D} \leq 30 \mathrm{ng} / \mathrm{mL}(\mathrm{n}=28)\end{array}$ & $\begin{array}{l}\text { Vitamin D } 1200 \text { IU daily if serum } 25(\mathrm{OH}) \mathrm{D} \text { was } 20 \text { to } 29 \\
\mathrm{ng} / \mathrm{mL} \text { or } 50,000 \mathrm{IU} \text { weekly if serum } 25(\mathrm{OH}) \mathrm{D}<20 \mathrm{ng} / \mathrm{mL} \\
3 \text { months }\end{array}$ & $\begin{array}{c}\downarrow \text { pain } \\
\uparrow \text { sleep duration } \\
\uparrow \text { general health } \\
\uparrow \text { vitality } \\
\uparrow \text { social functioning }\end{array}$ & [81] \\
\hline Veterans with PTDS $(\mathrm{n}=21)$ & $\begin{array}{l}\text { Sentra AM: Choline bitartrate }(250 \mathrm{mg}) \text {, Cocoa extract }(6 \% \\
\text { Theobromine) }(70 \mathrm{mg}) \text {, l-Glutamic acid (40mg), Acetyl 1- } \\
\text { carnitine ( } 40 \mathrm{mg}) \text {, Ginkgo biloba }(25 \mathrm{mg}) \text {, Hawthorne crataegus } \\
\text { spp. }(15 \mathrm{mg}) \text { and minerals (calcium and magnesium). } \\
\text { Sentra PM: Sentra AM + Griffonia extract }(5.5 \mathrm{mg}) \text {. } \\
\text { Two capsules ( } 950 \mathrm{mg}) \text { of Sentra AM in the morning and two } \\
\text { capsules }(961 \mathrm{mg}) \text { of Sentra PM at bedtime, } 30 \text { days. }\end{array}$ & $\begin{array}{l}\downarrow \text { PTSD symptoms } \\
\leftrightarrow \text { Physical health (trend ns in- } \\
\text { crease) }\end{array}$ & {$[82]$} \\
\hline
\end{tabular}

25(OH)D: 25-hydroxyvitamin D; CKD: Chronic kidney disease; GAD: Generalized anxiety disorder; GWI: Gulf War illness; ICU: intensive care unit; MCI: Mild cognitive impairment; MDD: Major depressive disorder; PTSD: posttraumatic stress disorder. 
Gulf War illness (GWI) [75], improved cognition has been observed after treatment with Bacopa monnieri extract [70], Dangguijagyag-san [77], pycnogenol [69] and L-carnosine [75], but the latter one did not affect fatigue, pain and hyperalgesia (Table 1).

Pain reduction, as well as improved general health, was observed in veterans with chronic pain and low baseline 25hydroxyvitamin D $(25(\mathrm{OH}) \mathrm{D})$ after vitamin D supplementation [81]. However, such supplementation did not improve physical performance [80].

On the other hand, Centella asiatica extract increased physical performance in the elderly [71].

Concerning anxiety and depression, improvements have been found in the majority of studies with nutraceuticals and herbal extracts $[73,74,76,78]$. Furthermore, two nutraceuticals, containing amino acids, minerals and extracts (cocoa, Ginkgo biloba, Hawthorne crataegus spp. with or without Griffonia), reduced PTSD symptoms in veterans [82].

Despite the potential therapeutic effects of medicinal herbs and phytochemicals on depression [83] and neurodegeneration [84], self-prescription and potential adverse effects must be taken into account.

In a retrospective study, 10 out of $20(50 \%)$ patients with fulminant hepatic failure were recent or active users of potentially hepatotoxic supplements or herbs [85].

The use and self-prescription of nutritional supplements and herbal extracts are common in veterans [86-88]. In addition to the risk of medication substitution [87], it has been reported that veterans with dementia and/or depression who used herbal products were also taking potentially interacting drugs [89].

The potential risk of interaction between a dietary supplement and prescription medication was also identified in veterans with cancer taking supplementations [90].

Polypharmacy (five or more daily drugs) is common in older people for managing comorbidities [91-93] and is a well-known problem in the management of the psychiatric elderly [95], and an independent risk factor for delirium in older patients after emergency admission [96].

Inappropriate prescriptions [97-100] and potential prescription omissions [98] have also been documented. Moreover, multiple medications are frequently used in patients with PTSD and traumatic brain injury $[101,102]$, as well as in the management of chronic pain [103-106].

In general, multimorbidity and polypharmacy are associated with malnutrition [107], as well as to the occurrence of adverse drug reactions [99, 108, 109], and Central Nervous System Polypharmacy is associated with drug/alcohol overdose and suicide in veterans [110], among whom prevalence of depression [111] and alcohol use disorders [112] are higher. Therefore, veterans, like the elderly, are a clinically vulnerable group which is worth monitoring carefully for potential herb- and nutraceutical-drug interactions [113-116].

Particular attention requires the use of green tea catechins [115118], both in form of extract and tea infusion, and Hypericum perforatum $[119,120]$. Therefore, herbal infusion should not be considered as a water equivalent for water balance (Fig. 1).

Possible interactions with drugs have also been suggested for mineral-fortified foods and fruit juices [121-123]. In this context, the Spanish Society of Community Nutrition (SENC) included some concerns about supplementation and nutraceuticals as personalized option in the pyramid for the 2016 Dietary Guidelines for general population [124] (Fig. 1).

\section{HEALTHY DIET FOR VETERANS}

Malnutrition is associated with higher mortality rates in veterans [125], in particular in the elderly [126], and food insecurity affects the low diet quality in veterans [127-129]. In overweight and obese veterans, low fruit and vegetable consumption is often associated with tobacco use [130]. Unhealthy dietary and lifestyle habits, including smoke, are common in veterans [131-133], increasing the risk of cancer and cardiovascular diseases (CVD) [134].

Mental illness is also related with poor nutrition [132, 133] and both PTSD and depression are associated with binge eating disorders in veterans [135]. Data from meta-analysis indicated that subjects with PTSD had a high risk of developing impaired memory [136], Type 2 diabetes mellitus [137], CVD [138] and metabolic syndrome [139]. In this context, it must be taken into account that the anthropometric parameters in injured veterans are not comparable to ablebodied people. In particular, erroneous estimations of anthropometric measurements can occur in amputates classifying unilateral amputates as thinner and the bilateral ones more obese than they actually are [140]. Moreover, it has been suggested that subjects with spinal cord injury have distinct physiological characteristics from the ablebodied adults, making difficult the estimate of the prevalence of carbohydrates and lipid disorder, of the potential impact of exercise and of the pharmacological therapies and dietary interventions [141] Contrary to the mindfulness-based stress reduction, which did not improve dietary habit in veterans [142], integrated approaches, such as "Lifestyle Balance" (modified from the Diabetes Prevention Program) [143], gave promising results. The weight management MOVE! included a self-management support of both physical activity and dietary habit $[144,145]$. In obese veterans with schizophrenia, treated with clozapine, an intervention including both dietary control, with a reduction of 200-300 Kcal/day (1600-1800 Kcal/day men and $1300-1500 \mathrm{Kcal} /$ day women), and regular physical activity (walking and walking stairs for $60 \mathrm{~min}$. 3days a week used approximately 600$750 \mathrm{kcal}$ per week) reduced body weight, insulin metabolic profile and triglyceride, compared to the controls [146].

On the other hand, it is well recognized the role of dietary habits in metabolic control in veterans [147] and that plant foods consumption is associated with high cognitive performance $[148,149]$.

The potential of the Mediterranean diet in disease prevention has been related to the favorable effect of a balanced ratio of omega 6 and omega-3 polyunsaturated fatty acids and of high amounts of fiber and polyphenols found in fruit, vegetables and olive oil $[56,150]$. Nonlinear relationships are often observed between plant foods consumption and cognitive function. Increasing cognitive performance with increasing intakes of potatoes or grain products reached a plateau or started to decrease at about $100-150 \mathrm{~g} / \mathrm{d}$ [149]. The associations between cognition and combined intake of fruit and vegetables were strongest, with a marked dose-dependent relationship up to about 500 $\mathrm{g} / \mathrm{d}$ [149]. In particular, the favorable effects of just taking vegetable reached a maximum at a dose of about $150-200 \mathrm{~g} / \mathrm{d}$ and for fruit at around $300 \mathrm{~g} / \mathrm{d}$ [149]. Therefore, the fruit/vegetables intake probably should range between the $400 \mathrm{~g} / \mathrm{d}$ suggested by the WHO [151] (i.e. 5 servings of $80 \mathrm{~g}$ ) and up to 3 servings of $150 / 200 \mathrm{~g}$ as suggested by Vitiello et al. in the new Mediterranean diet Italian Pyramid [152].

On the other hand, it has been reported that a high intake (10 servings daily) of fruit and vegetable, including cruciferous vegetables (broccoli, cabbage, and daikon radish sprouts), soy foods (soy milk, veggies slices, tofu, and roasted soy nuts), and citrus fruits (grapefruit and orange juices, orange/grapefruit segments, and dried orange peel) affected the pharmacokinetic of paracetamol [153]. Therefore, the presence of glucosinolates, flavonoids and furanocoumarins in some plant foods and beverages must be taken into consideration owing to their potential interfering with drugs metabolism and bioavailability, despite the positive association between cognitive function and consumption of cruciferous vegetables and citrus fruits [149]. Interactions between drugs and natural fruit juices have been reported, especially grapefruit juice $[154,155]$ but also cranberry [156] and pomegranate [157] juices, a quercetin containing muscadine grape [158] and soy protein [159]. Accordingly, considering the high content of bioactive compounds and phytochemicals in plant 
foods [160], a personalized nutrition (Figure 1) should take into account potential food-drug interactions in veterans who are in treatment for comorbidities. In agreement, dietetic interventions based on personalized dietary advice have also been suggested for old subjects [161], in order to avoid potential food-drug interactions [162-170]. In particular, the effect of high-protein, low-carbohydrate diets on warfarin efficacy should be taken into consideration $[169,170]$. In this context, nitrogen balance should be the aim of dietary regimes (Fig. 1) even when dietetic restriction is required for the weight management.

\section{PHYSICAL ACTIVITY FOR VETERANS}

Exercise capacity is inversely related to mortality in older veterans [171] and there is wide agreement on the importance of physical activity programs in veterans [172-174], in order to improve mobility in frail elders [175] and to reduce obesity $[145,176]$ and mortality in hypertensive veterans [145, 177], as documented by the STRIDE program [178] and the Project LIFE [179]. In particular, cardiorespiratory fitness has been suggested as one of the factors involved in the obesity paradox (i.e. higher BMI associated with better survival) $[180,181]$. However, physical inactivity can be imposed by pathological conditions, such as lower extremity amputation, and it has been underlined that over half of overweight and obese veterans reported the intention to lose weight, but only a few reported having followed a complete weight loss path, highlighting an unsatisfied need to draw on an external support of psychological and physical nature during their program [182].

In addition to the adoption of diets and eating habits, veterans have also been involved in sports during their rehabilitation processes, with the resulting evidence that sports practice in association with a proper food intake can lead individuals with motor disabilities and mental impairments to excel in some disciplines in order to achieve elite levels, giving rise to the phenomenon of the Paralympics and the development of "recreational therapy" [183].

Low physical activity has also been suggested as one of the factors involved in the high prevalence of osteoporosis and osteopenia in overweight/obese veterans with a sedentary lifestyle [184]. However, in the management of veterans unable to walk should be considered some characterizing aspects and risks, such as the possibility of fractures occurring. Falls are strongly associated with benzodiazepines, neuroleptics, antidepressants and anti-hypertensives [108]. Therefore, polypharmacy and mental health can affect the risk of fracture. On the other hand, in hospitalized people or in nursing homes the presence of fractures of the hip was related to an insufficient intake of vitamin D or to an incorrect reintegration of vitamin D [185-188]. This problem was found in association with an incorrect diagnosis of osteoporosis and an inadequate recognition of the problem at the time of patient acceptance in the nursing home. The scientific evidence highlights the need to develop adequate vitamin D integration protocols in those patients with reduced mobility, who are therefore subjected to treatments that include hospitalization in healthcare facilities and not. Investigating the incidence of hip fractures in the lower limbs or hip with the administration of vitamin D or calcium supplements, some studies have highlighted that a preventive intake of supplements, such as calcium and vitamin D, before hospitalization of patients leads to a lower risk of fracture development [189-191]. These studies have showed how the lifestyle of these people, often subjected to wheelchair ambulation, exposed them to greater risks of fractures, which may occur during the transfer phases to and from wheelchairs. The same studies have found a relationship between vitamin D deficiency and diseases, such as hypertension, cancer, CVD and diabetes mellitus. Other causes involved in low vitamin D levels included the admission in nursing homes and consequent not adequate exposure to sunlight, comorbidity and physiological decrease of vitamin D due to age. In this context, it has been suggested that outdoor lifestyle, through vitamin D synthesis, could account for Mediterranean lifestyle health benefits [192] (Fig. 1). Furthermore, it has been reported that older adults with high adherence to Mediterranean diet had faster walking speed and were more likely to have a greater physical activity $[193,194]$ which was associated with a higher cognitive function [195].

\section{LIFESTYLE AND ENVIRONMENTAL FACTORS}

It has been suggested that both physical and cognitive activity components should be taken into consideration in lifestyle interventions for veterans [196].

There is a broad consensus that adherence to Mediterranean diet, particularly in conjunction with social interaction and physical activity, prevents cognitive frailty in the elderly [194, 197-200], as well as depression [195, 201].

Physical activity and plant foods intake are within the major recommendations in graphical representations of healthy diet worldwide [202, 203], as well as in the Double Pyramid Model and in the Iberoamerican Nutrition Foundation (FINUT) pyramid of healthy lifestyles [204], considering also the dietary environmental impact [205], which could have a positive influence on veterans. In this context, in veterans with mental illness lifestyle changes, such as exercise, diet, relaxation, time in nature, relationships and service to others, improve quality of life, weight loss and diastolic blood pressure [133]. Moreover, non-pharmacological intervention programs which have been suggested for cognitive impairment and depression, with promising results in the elderly [205] or veterans [207], include pet of insects [206] and horticultural therapy [207].

Furthermore, even conviviality and culinary activities are included in the new Mediterranean diet pyramid [208, 209] and in the FINUT pyramid [210]. In particular, it has been suggested that conviviality, improving socialization, could be one of the determining factors in the health benefits of Mediterranean lifestyle [192]. In addition to conviviality, the SENC included the emotional balance in the pyramid [124]. In this context, in veterans with spinal cord injury, marital status and living arrangement are positively related to higher self-care behaviors [211] and a family focused therapy has been suggested for rehabilitation of veterans with traumatic brain injury [212].

On the other hand, loneliness has been identified as an important factor involved in depression and suicidal ideation in veterans [213]. In addition to PTSD, delayed-onset ( $>6$ months) PTSD was almost twice in veterans compared to non-professional victims [214]. Posttrauma, low social and family supports are both associated with the PTSD occurrence [215] and veterans exposed to wartime combat are more susceptible to subsequent stressors [216], in particular during ageing [217, 218]. For this reason, we have integrated in the suggested Mediterranean pyramid for veterans (Fig. 1), starting from the base, the previous indications of emotional balance, traditions, conviviality, frugality, sustainability and seasonality with culinary and horticultural activities, outdoor live and psychological wellness. The latter one is strictly connected to physical activity and physical performance. Recommendation for physical activity range at least between 30 [152] and 60 (SENC) per day. However, the evaluation of mood, clinical and nutritional status should drive personalized lifestyle and rehabilitation/training programs in veterans with disabilities (Fig. 1), including training for Paralympics competitions [183].

As previously suggested, seasonality implies the "intermittent" consumption of different foods, which contain a variable mix of bioactive molecules, and it allows to prevent the onset of phenomena of tolerance that might otherwise occur with the chronic intake of a single flavonoid or with a same food source of flavonoids. Although variability could also ensure the maintenance of the single dose of flavonoid below that at which adverse effects in some individuals genetically predisposed or unpleasant drug interactions in diseased subjects may occur [219], probably the avoidance of foods and beverages with high content of phytochemicals [117, 149, 153-159] could be recommended in subjects under polypharmacy regimes. In 
these patients, plant foods should be chosen within those containing low phytochemicals and high micronutrients. If this aim is difficult to reach, vitamins and/or minerals supplementation can be indicated (top of the Pyramid) (Fig. 1).

In the middle of the pyramid, there are energy, nitrogen and water balance, as well as nutrient requirement coverage (Fig. 1). Although the frequency of consumption should be (every meal: cereals, vegetables and fruit; every day: milk or yogurt and olive oil; every week: meat, fish, eggs, cheese, pulses, potatoes, carrots and nuts) similar to the previously indicated ones [152], non-nutrient herbs and spices to flavor dishes and herbal infusions have been added to comfort and luxury foods and beverages (sweet, cocoa, coffee, tea, beer and wine). Occasional and/or moderate consumption should be suggested for this category, taking also into account potential interactions of phytochemicals with drugs and the effects on water and energy balance. However, the potential effects on mood should also be considered [220, 221].

\section{CONCLUSION}

Veterans with multimorbidity often identified specific self-care approaches for disease management, including both medication, healthy lifestyle practices and CAM [222].

The role of pharmacists in the elderly with polypharmacy has been previously suggested [223-225]. In this context, personalized nutrition could also have a role in the prevention of drug-food interactions [226] and in the plan of integrating programs for healthy ageing in veterans with disabilities.

In conclusion, although the Mediterranean Pyramid could be the basis for integrative medicine for veterans with disabilities, patientcentered approaches and interprofessional (including physical medicine and rehabilitation clinicians, pharmacists and nutritionists) interventions could be useful.

\section{LIST OF ABBREVIATIONS}

$\begin{array}{lll}25(\mathrm{OH}) \mathrm{D}= & & \text { 25-hydroxyvitamin D } \\ \mathrm{ACS} & = & \text { American Community Survey } \\ \mathrm{CAM} & = & \text { Complementary and alternative medicine } \\ \mathrm{CKD} & = & \text { chronic kidney disease } \\ \text { CVD } & = & \text { Gulf War illness } \\ \text { GWI } & = & \text { post-traumatic stress disorder } \\ \text { MCI } & \text { Spanish Society of Community Nutrition }\end{array}$

\section{CONSENT FOR PUBLICATION}

Not applicable.

\section{CONFLICT OF INTEREST} wise.

The authors declare no conflict of interest, financial or other-

\section{ACKNOWLEDGEMENTS}

Declared none.

\section{REFERENCES}

[1] Holder KA. The Disability of Veterans, Social, Economic, and Housing Statistics Division, US. Whashinghton, DC Available from:

https://www.census.gov/content/dam/Census/library/workingpapers/2016/demo/Holder-2016-01.pdfAvailable

[2] Korinek K, Loebach P, Teerawichitchainan B. Physical and Mental Health Consequences of War-related Stressors Among Older
Adults: An Analysis of Posttraumatic Stress Disorder and Arthritis in Northern Vietnamese War Survivors. J Gerontol B Psychol Sci Soc Sci 2017; 72(6): 1090-102.

[3] Xue $\mathrm{C}, \mathrm{Ge} \mathrm{Y}$, Tang $\mathrm{B}$, et al A meta-analysis of risk factors for combat-related PTSD among military personnel and veterans. PLoS One 2015; 10(3): e0120270.

[4] Fulton JJ, Calhoun PS, Wagner HR et al The prevalence of posttraumatic stress disorder in Operation Enduring Freedom/Operation Iraqi Freedom (OEF/OIF) Veterans: A meta-analysis. J Anxiety Disord 2015; 31: 98-107.

[5] Solomon Z, Mikulincer M. Trajectories of PTSD: A 20-year longitudinal study. Am J Psychiatry 2006; 163(4): 659-66.

[6] Pietrzak RH, Tsai J, Kirwin PD, Southwick SM. Successful aging among older veterans in the United States. Am J Geriatr Psychiatry 2014; 22(6): 551-63.

[7] Solomon Z, Helvitz H, Zerach G. Subjective age, PTSD and physical health among war veterans. Aging Ment Health 2009; 13(3): 405-13.

[8] Ben-Shalom Y, Tennant JR, Stapleton DC. Trends in disability and program participation among U.S. veterans. Disabil Health J 2016; 9(3): 449-56.

[9] La Croix AZ, Rillamas-Sun E, Woods NF, et al. Aging well among women veterans compared with non-veterans in the Women's Health initiative. Gerontologist 2016; 56: 14-26.

[10] Thomas HV, Stimpson NJ, Weightman A, Dunstan F, Lewis G. Pain in veterans of the Gulf War of 1991: A systematic review. BMC Musculoskelet Disord 2006; 7: 74.

[11] Nahin RL. Severe pain in veterans: The effect of age and sex, and comparisons with the general population. J Pain 2017; 18(3): $247-$ 54.

[12] Driscoll MA, Higgins D, Shamaskin-Garroway A, et al. Examining gender as a correlate of self-reported pain treatment use among recent service veterans with deployment-related musculoskeletal disorders. Pain Med 2017; 18(9): 1767-77.

[13] Thomas HV, Stimpson NJ, Weightman AL, Dunstan F, Lewis G. Systematic review of multi-symptom conditions in Gulf War veterans. Psychol Med 2006; 36(6): 735-47.

[14] Samuelson KW, Neylan TC, Lenoci M, et al. Longitudinal effects of PTSD on memory functioning. J Int Neuropsychol Soc 2009 15(6): 853-61.

[15] Chung PJ, Chiou CJ, Chou FH. Relationships between health status, depression and cognitive functions of institutionalized male veterans. Arch Gerontol Geriatr 2009; 49(2): 215-9.

[16] Mather AA, Stein MB, Sareen J. Social anxiety disorder and social fears in the Canadian military: prevalence, comorbidity, impairment, and treatment-seeking. J Psychiatr Res 2010; 44(14): 887-93.

[17] Haagen JF, Smid GE, Knipscheer JW, Kleber RJ. The efficacy of recommended treatments for veterans with PTSD: A metaregression analysis. Clin Psychol Rev 2015; 40: 184-94.

[18] Puetz TW, Youngstedt SD, Herring MP. Effects of pharmacotherapy on combat-related PTSD, Anxiety, and depression: A systematic review and meta-regression analysis. PLoS One 2015; 10(5): e0126529.

[19] De Berardis D, Marini S, Serroni N, et al. Targeting the noradrenergic system in posttraumatic stress disorder: a systematic review and meta-analysis of prazosin trials. Curr Drug Targets 2015; 16(10): 1094-106.

[20] Watts BV, Schnurr PP, Mayo L, Young-Xu Y, Weeks WB, Friedman MJ. Meta-analysis of the efficacy of treatments for posttraumatic stress disorder. J Clin Psychiatry 2013; 74(6): e541-50.

[21] Hull A, Reinhard M, McCarron K, et al. Acupuncture and meditation for military veterans: first steps of quality management and future program development. Glob Adv Health Med 2014; 3(4): $27-$ 31.

[22] Heffner KL, Crean HF, Kemp JE. Meditation programs for veterans with posttraumatic stress disorder: Aggregate findings from a multi-site evaluation. Psychol Trauma 2016; 8(3): 365-74.

[23] Kearney DJ, McManus C, Malte CA, Martinez ME, Felleman B, Simpson TL. Loving-kindness meditation and the broaden-andbuild theory of positive emotions among veterans with posttraumatic stress disorder. Med Care 2014; 52(12)(Suppl. 5): S32-8.

[24] Kearney DJ, McDermott K, Malte C, Martinez M, Simpson TL. Effects of participation in a mindfulness program for veterans with posttraumatic stress disorder: A randomized controlled pilot study. J Clin Psychol 2013; 69(1): 14-27. 
[24] Kearney DJ, McDermott K, Malte C, Martinez M, Simpson TL. Effects of participation in a mindfulness program for veterans with posttraumatic stress disorder: A randomized controlled pilot study. J Clin Psychol 2013; 69(1): 14-27.

[26] Carlson KJ, Silva SG, Langley J, Johnson C. Mindful-Veteran: The implementation of a brief stress reduction course. Complement Ther Clin Pract 2013; 19(2): 89-96.

[27] Koszycki D, Thake J, Mavounza C, Daoust JP, Taljaard M, Bradwejn J. Preliminary Investigation of a Mindfulness-Based Intervention for Social Anxiety Disorder That Integrates Compassion Meditation and Mindful Exposure. J Altern Complement Med 2016; 22(5): 363-74.

[28] Khusid MA, Vythilingam M. the emerging role of mindfulness meditation as effective self-management strategy, Part 1: clinical implications for depression, post-traumatic stress disorder, and anxiety. Mil Med 2016; 181(9): 961-8.

[29] Serpa JG, Taylor SL, Tillisch K. Mindfulness-based stress reduction (MBSR) reduces anxiety, depression, and suicidal ideation in veterans. Med Care 2014; 52(12)(Suppl. 5): S19-24.

[30] King CH, Moore LC, Spence CD. Exploring self-reported benefits of auricular acupuncture among veterans with posttraumatic stress disorder. J Holist Nurs 2016; 34(3): 291-9.

[31] Juberg M, Jerger KK, Allen KD, Dmitrieva NO, Keever T, Perlman AI. Pilot study of massage in veterans with knee osteoarthritis. J Altern Complement Med 2015; 21(6): 333-8.

[32] Groessl EJ, Weingart KR, Johnson N, Baxi S. The benefits of yoga for women veterans with chronic low back pain. J Altern Complement Med 2012; 18(9): 832-8.

[33] Groessl EJ, Weingart KR, Aschbacher K, Pada L, Baxi S. Yoga for veterans with chronic low-back pain. J Altern Complement Med 2008; 14(9): 1123-9.

[34] Libby DJ, Reddy F, Pilver CE, Desai RA. The use of yoga in specialized VA PTSD treatment programs. Int J Yoga Therap 2012; 22(22): 79-87.

[35] Schulz-Heik RJ, Meyer H, Mahoney L, et al. Results from a clinical yoga program for veterans: yoga via telehealth provides comparable satisfaction and health improvements to in-person yoga. BMC Complement Altern Med 2017; 17(1): 198.

[36] Stankovic L. Transforming trauma: A qualitative feasibility study of integrative restoration (iRest) yoga Nidra on combat-related post-traumatic stress disorder. Int J Yoga Therap 2011; 21(21): 2337.

[37] Hull A, Holliday SB, Eickhoff C, Rose-Boyce M, Sullivan P, Reinhard M. the integrative health and wellness program: Development and use of a complementary and alternative medicine clinic for veterans. Altern Ther Health Med 2015; 21(6): 12-21.

[38] Holliday SB, Hull A, Lockwood C, Eickhoff C, Sullivan P, Reinhard M. Physical health, mental health, and utilization of complementary and alternative medicine services among Gulf War veterans. Med Care 2014; 52(12)(Suppl. 5): S39-44.

[39] Libby DJ, Pilver CE, Desai R. Complementary and alternative medicine in VA specialized PTSD treatment programs. Psychiatr Serv 2012; 63(11): 1134-6.

[40] Chao MT, Wade C, Kronenberg F, Kalmuss D, Cushman LF. Women's reasons for complementary and alternative medicine use: racial/ethnic differences. J Altern Complement Med 2006; 12(8): 719-22.

[41] Chao MT, Wade CM. Socioeconomic factors and women's use of complementary and alternative medicine in four racial/ethnic groups. Ethn Dis 2008; 18(1): 65-71.

[42] Neiberg RH, Aickin M, Grzywacz JG, et al. Occurrence and cooccurrence of types of complementary and alternative medicine use by age, gender, ethnicity, and education among adults in the United States: the 2002 National Health Interview Survey (NHIS). J Altern Complement Med 2011; 17(4): 363-70.

[43] Park CL, Finkelstein-Fox L, Barnes DM, Mazure CM, Hoff R. CAM use in recently-returned OEF/OIF/OND US veterans: Demographic and psychosocial predictors. Complement Ther Med 2016; 28: 50-6.

[44] Elwy AR, Johnston JM, Bormann JE, Hull A, Taylor SL. A systematic scoping review of complementary and alternative medicine mind and body practices to improve the health of veterans and military personnel. Med Care 2014; 52(12)(Suppl. 5): S70-82.

[45] McEachrane-Gross FP, Liebschutz JM, Berlowitz D. Use of selected complementary and alternative medicine (CAM) treatments in veterans with cancer or chronic pain: A cross-sectional survey. BMC Complement Altern Med 2006; 6: 34

[46] Whitehead A, Gould Fogerite S. Yoga Treatment for Chronic NonSpecific Low Back Pain (2017). Explore (NY) 2017; 13(4): 281-4.

[47] Highland KB, Schoomaker A, Rojas W, et al. Benefits of the restorative exercise and strength training for operational resilience and excellence yoga program for chronic low back pain in service members: A pilot randomized controlled trial. Arch Phys Med Rehabil 2018; 99(1): 91-8.

[48] Orme-Johnson DW, Barnes VA. Effects of the transcendental meditation technique on trait anxiety: A meta-analysis of randomized controlled trials. J Altern Complement Med 2014; 20(5): 33041.

[49] Marmar CR, Schlenger W, Henn-Haase C, et al. Course of Posttraumatic Stress Disorder 40 Years After the Vietnam War: Findings From the National Vietnam Veterans Longitudinal Study. JAMA Psychiatry 2015; 72(9): 875-81.

[50] Bartoli F, Crocamo C, Clerici M, Carrà G. The association between PTSD and metabolic syndrome: A role for comorbid depression? Metabolism 2015; 64(11): 1373-5.

[51] Lagonia P, Aloi M, Magliocco F, et al. First World War and Mental Health: A retrospective comparative study of veterans admitted to a psychiatric hospital between 1915 and 1918. Riv Psichiatr 2017; 52(3): 120-5

[52] Bonfiglioli Stagni S, Tomba P, Viganò A, Zati A, Benedetti MG. The first world war drives rehabilitation toward the modern concepts of disability and participation. Eur J Phys Rehabil Med 2015; 51(3): 331-6.

[53] Loscalzo Y, Giannini M, Gori A, Fabio AD. The wellbeing of italian peacekeeper military: Psychological resources, quality of life and internalizing symptoms front psychol (13): 9-103.2018;

[54] Vasto S, Barera A, Rizzo C, Di Carlo M, Caruso C, Panotopoulos G. Mediterranean diet and longevity: An example of nutraceuticals? Curr Vasc Pharmacol 2014; 12(5): 735-8.

[55] Chatzianagnostou K, Del Turco S, Pingitore A, Sabatino L, Vassalle C. The mediterranean lifestyle as a non-pharmacological and natural antioxidant for healthy aging. Antioxidants 2015; 4(4): 71936.

[56] Peluso I, Romanelli L, Palmery M. Interactions between prebiotics, probiotics, polyunsaturated fatty acids and polyphenols: diet or supplementation for metabolic syndrome prevention? Int J Food Sci Nutr 2014; 65(3): 259-67.

[57] Who World Report on Disability 2011 Geneve World Health Organization

[58] van der Pols JC, Kanesarajah J, Bell A, Lui CW. Current dietary supplement use of Australian military veterans of Middle East operations. Public Health Nutr 2017; 20(17): 3156-65.

[59] Wu CH, Wang CC, Tsai MT, Huang WT, Kennedy J. Trend and pattern of herb and supplement use in the United States: results from the 2002, 2007, and 2012 national health interview surveys. Evid Based Complement Alternat Med 2014; 2014: 872320.

[60] Astin JA, Pelletier KR, Marie A, Haskell WL. Complementary and alternative medicine use among elderly persons: one-year analysis of a Blue Shield Medicare supplement. J Gerontol A Biol Sci Med Sci 2000; 55(1): M4-9.

[61] Aschemann-Witzel J, Grunert KG. Resveratrol food supplements: A survey on the role of individual consumer characteristics in predicting the attitudes and adoption intentions of US American and Danish respondents. BMC Public Health 2015; 15: 110.

[62] Badger F, Nolan P. Use of self-chosen therapies by depressed people in primary care. J Clin Nurs 2007; 16(7): 1343-52.

[63] Wu CH, Kennedy J, Sclar DA. Factors associated with the use of St. John's wort among adults with depressive symptoms. J Diet Suppl 2008; 5(4): 341-8.

[64] Jarman CN, Perron BE, Kilbourne AM, Teh CF. Perceived treatment effectiveness, medication compliance, and complementary and alternative medicine use among veterans with bipolar disorder. J Altern Complement Med 2010; 16(3): 251-5.

[65] Betthauser LM, Brenner LA, Forster JE, Hostetter TA, Schneider AL, Hernández TD. A factor analysis and exploration of attitudes and beliefs toward complementary and conventional medicine in veterans. Med Care 2014; 52(12)(Suppl. 5): S50-6.

[66] Asher GN, Gartlehner G, Gaynes BN, et al. Comparative benefits and harms of complementary and alternative medicine therapies for initial treatment of major depressive disorder: systematic review 
and meta-analysis. J Altern Complement Med 2017; 23(12): 90719.

[67] Brady CB, Gaziano JM, Cxypoliski RA, et al. Homocysteine lowering and cognition in CKD: the Veterans Affairs homocysteine study. Am J Kidney Dis 2009; 54(3): 440-9.

[68] Mao JJ, Xie SX, Zee J, et al. Rhodiola rosea versus sertraline for major depressive disorder: A randomized placebo-controlled trial. Phytomedicine 2015; 22(3): 394-9.

[69] Ryan J, Croft K, Mori T, et al. An examination of the effects of the antioxidant Pycnogenol on cognitive performance, serum lipid profile, endocrinological and oxidative stress biomarkers in an elderly population. J Psychopharmacol (Oxford) 2008; 22(5): 553-62.

[70] Calabrese C, Gregory WL, Leo M, Kraemer D, Bone K, Oken B. Effects of a standardized Bacopa monnieri extract on cognitive performance, anxiety, and depression in the elderly: A randomized, double-blind, placebo-controlled trial. J Altern Complement Med 2008; 14(6): 707-13.

[71] Mato L, Wattanathorn J, Muchimapura S, et al. Centella asiatica improves physical performance and health-related quality of life in healthy elderly volunteer. Evid Based Complement Alternat Med 2011; 2011 : 579467 .

[72] Robinson TN, Dunn CL, Adams JC, et al. Tryptophan supplementation and postoperative delirium--a randomized controlled trial. J Am Geriatr Soc 2014; 62(9): 1764-71.

[73] Bystritsky A, Kerwin L, Feusner JD. A pilot study of Rhodiola rosea (Rhodax) for generalized anxiety disorder (GAD). J Altern Complement Med 2008; 14(2): 175-80.

[74] Tubaki BR, Chandrashekar CR, Sudhakar D, Prabha TN, Lavekar GS, Kutty BM. Clinical efficacy of Manasamitra Vataka (an Ayurveda medication) on generalized anxiety disorder with comorbid generalized social phobia: A randomized controlled study. J Altern Complement Med 2012; 18(6): 612-21.

[75] Baraniuk JN, El-Amin S, Corey R, Rayhan R, Timbol C. Carnosine treatment for gulf war illness: A randomized controlled trial. Glob J Health Sci 2013; 5(3): 69-81.

[76] Kolouri S, Firoozabadi A, Salehi A, et al. Nepeta menthoides Boiss. \& Buhse freeze-dried aqueous extract versus sertraline in the treatment of major depression: A double blind randomized controlled trial. Complement Ther Med 2016; 26: 164-70.

[77] Kim KH, Go HY, Lee JA, et al. The Effect of Dangguijagyag-san on Mild Cognitive Impairment. J Altern Complement Med 2016; 22(7): 509-14

[78] Panahi Y, Badeli R, Karami GR, Badeli Z, Sahebkar A. A randomized controlled trial of 6-week Chlorella vulgaris supplementation in patients with major depressive disorder. Complement Ther Med 2015; 23(4): 598-602

[79] Zhang WF, Tan YL, Zhang XY, Chan RC, Wu HR, Zhou DF. Extract of Ginkgo biloba treatment for tardive dyskinesia in schizophrenia: A randomized, double-blind, placebo-controlled trial. J Clin Psychiatry 2011; 72(5): 615-21.

[80] Levis S, Gómez-Marín O. Vitamin D and physical function in sedentary older men. J Am Geriatr Soc 2017; 65(2): 323-31.

[81] Huang W, Shah S, Long Q, Crankshaw AK, Tangpricha V. Improvement of pain, sleep, and quality of life in chronic pain patients with vitamin D supplementation. Clin J Pain 2013; 29(4): 341-7.

[82] Shell WE, Charuvastra M, Breitstein M, et al. Administration of an amino Acid-based regimen for the management of autonomic nervous system dysfunction related to combat-induced illness. J Cent Nerv Syst Dis 2014; 6: 93-8

[83] Lee G, Bae H. Therapeutic Effects of phytochemicals and medicinal herbs on depression. BioMed Res Int 2017; 2017: 6596241.

[84] Perry E, Howes MJ. Medicinal plants and dementia therapy: herbal hopes for brain aging? CNS Neurosci Ther 2011; 17(6): 683-98.

[85] Estes JD, Stolpman D, Olyaei A, et al. High prevalence of potentially hepatotoxic herbal supplement use in patients with fulminant hepatic failure. Arch Surg 2003; 138(8): 852-8.

[86] Tarn DM, Guzmán JR, Good JS, Wenger NS, Coulter ID, Paterniti DA. Provider and patient expectations for dietary supplement discussions. J Gen Intern Med 2014; 29(9): 1242-9.

[87] Goldstein JN, Long JA, Arevalo D, Ibrahim SA, Mao JJ. US veterans use vitamins and supplements as substitutes for prescription medication. Med Care 2014; 52(12)(Suppl. 5): S65-9.

[88] Jazieh AR, Kopp M, Foraida M, et al. The use of dietary supplements by veterans with cancer. J Altern Complement Med 2004; 10(3): 560-4.
[89] Kales HC, Blow FC, Welsh DE, Mellow AM. Herbal products and other supplements: use by elderly veterans with depression and dementia and their caregivers. J Geriatr Psychiatry Neurol 2004 17(1): 25-31.

[90] Lee AH, Ingraham SE, Kopp M, Foraida MI, Jazieh AR. The incidence of potential interactions between dietary supplements and prescription medications in cancer patients at a Veterans Administration Hospital. Am J Clin Oncol 2006; 29(2): 178-82.

[91] McNeil MJ, Kamal AH, Kutner JS, Ritchie CS, Abernethy AP. The burden of polypharmacy in patients near the end of life. J Pain Symptom Manage 2016; 51(2): 178-83.e2

[92] Wastesson JW, Canudas-Romo V, Lindahl-Jacobsen R, Johnell K. Remaining life expectancy with and without polypharmacy: A register-based study of swedes aged 65 years and older. J Am Med Dir Assoc 2016; 17(1): 31-5.

[93] Golchin N, Frank SH, Vince A, Isham L, Meropol SB. Polypharmacy in the elderly. J Res Pharm Pract 2015; 4(2): 85-8.

[94] Caughey GE, Roughead EE, Vitry AI, McDermott RA, Shakib S, Gilbert AL. Comorbidity in the elderly with diabetes: Identification of areas of potential treatment conflicts. Diabetes Res Clin Pract 2010; 87(3): 385-93.

[95] Langeard A, Pothier K, Morello R, et al. Polypharmacy Cut-Off for Gait and Cognitive Impairments Front Pharmacol 2016; 31: 7-296.

[96] Hein C, Forgues A, Piau A, Sommet A, Vellas B, Nourhashémi F. Impact of polypharmacy on occurrence of delirium in elderly emergency patients. J Am Med Dir Assoc 2014; 15(11): 850.e11-5.

[97] Soerensen AL, Nielsen LP, Poulsen BK, Lisby M, Mainz J. Potentially inappropriate prescriptions in patients admitted to a psychiatric hospital. Nord J Psychiatry 2016; 70(5): 365-73.

[98] Rongen S, Kramers C, O’Mahony D, Feuth TB, Olde Rikkert MG, Ahmed AI. Potentially inappropriate prescribing in older patients admitted to psychiatric hospital. Int J Geriatr Psychiatry 2016; 31(2): 137-45.

[99] Maher RL, Hanlon J, Hajjar ER. Clinical consequences of polypharmacy in elderly. Expert Opin Drug Saf 2014; 13(1): 57-65.

[100] Liu CL, Peng LN, Chen YT, Lin MH, Liu LK, Chen LK. Potentially inappropriate prescribing (IP) for elderly medical inpatients in Taiwan: A hospital-based study. Arch Gerontol Geriatr 2012; 55(1): 148-51

[101] Morgan M, Lockwood A, Steinke D, Schleenbaker R, Botts S. Pharmacotherapy regimens among patients with posttraumatic stress disorder and mild traumatic brain injury. Psychiatr Serv 2012; 63(2): 182-5.

[102] Bernardy NC, Lund BC, Alexander B, Friedman MJ. Increased polysedative use in veterans with posttraumatic stress disorder. Pain Med 2014; 15(7): 1083-90

[103] Nawai A, Leveille SG, Shmerling RH, van der Leeuw G, Bean JF. Pain severity and pharmacologic pain management among community-living older adults: The MOBILIZE Boston study. Aging Clin Exp Res 2017; 29(6): 1139-47.

[104] Barry DT, Sofuoglu M, Kerns RD, Wiechers IR, Rosenheck RA Prevalence and correlates of coprescribing anxiolytic medications with extensive prescription opioid use in Veterans Health Administration patients with metastatic cancer. J Opioid Manag 2016; 12(4): 259-68.

[105] Makris UE, Pugh MJ, Alvarez CA, et al. Exposure to High-Risk Medications is Associated With Worse Outcomes in Older Veterans With Chronic Pain. Am J Med Sci 2015; 350(4): 279-85.

[106] Oliva EM, Midboe AM, Lewis ET, et al. Sex differences in chronic pain management practices for patients receiving opioids from the Veterans Health Administration. Pain Med 2015; 16(1): 112-8.

[107] Zadak Z, Hyspler R, Ticha A, Vlcek J. Polypharmacy and malnutrition. Curr Opin Clin Nutr Metab Care 2013; 16(1): 50-5.

[108] Davies EA, O'Mahony MS. Adverse drug reactions in special populations - the elderly. Br J Clin Pharmacol 2015; 80(4): 796807.

[109] Calderón-Larrañaga A, Poblador-Plou B, González-Rubio F, Gimeno-Feliu LA, Abad-Díez JM, Prados-Torres A. Multimorbidity, polypharmacy, referrals, and adverse drug events: Are we doing things well? Br J Gen Pract 2012; 62(605): e821-6.

[110] Collett GA, Song K, Jaramillo CA, Potter JS, Finley EP, Pugh MJ. Prevalence of central nervous system polypharmacy and associations with overdose and suicide-related behaviors in Iraq and Afghanistan War Veterans in VA Care 2010-2011. Drugs Real World Outcomes 2016; 3(1): 45-52. 
[111] Blore JD, Sim MR, Forbes AB, Creamer MC, Kelsall HL. Depression in Gulf War veterans: A systematic review and meta-analysis. Psychol Med 2015; 45(8): 1565-80.

[112] Kelsall HL, Wijesinghe MS, Creamer MC, et al. Alcohol use and substance use disorders in Gulf War, Afghanistan, and Iraq War veterans compared with nondeployed military personnel. Epidemiol Rev 2015; 37: 38-54.

[113] Loya AM, González-Stuart A, Rivera JO. Prevalence of polypharmacy, polyherbacy, nutritional supplement use and potential product interactions among older adults living on the United StatesMexico border: A descriptive, questionnaire-based study. Drugs Aging 2009; 26(5): 423-36.

[114] Bunchorntavakul C, Reddy KR. Review article: herbal and dietary supplement hepatotoxicity. Aliment Pharmacol Ther 2013; 37(1): 3-17.

[115] Di Lorenzo C, Ceschi A, Kupferschmidt H, et al. Adverse effects of plant food supplements and botanical preparations: A systematic review with critical evaluation of causality. Br J Clin Pharmacol 2015; 79(4): 578-92.

[116] Teschke R, Wolff A, Frenzel C, Schulze J, Eickhoff A. Herbal hepatotoxicity: A tabular compilation of reported cases. Liver Int 2012; 32(10): 1543-56.

[117] An G, Mukker JK, Derendorf H, Frye RF. Enzyme- and transporter-mediated beverage-drug interactions: An update on fruit juices and green tea. J Clin Pharmacol 2015; 55(12): 1313-31.

[118] Mazzanti G, Di Sotto A, Vitalone A. Hepatotoxicity of green Tea: An update. Arch Toxicol 2015; 89(8): 1175-91.

[119] Chrubasik-Hausmann S, Vlachojannis J, McLachlan AJ. Understanding drug interactions with St John's wort (Hypericum perforatum L.): impact of hyperforin content. J Pharm Pharmacol 2018; 7.

[120] Soleymani S, Bahramsoltani R, Rahimi R, Abdollahi M. Clinical risks of St John's Wort (Hypericum perforatum) co-administration. Expert Opin Drug Metab Toxicol 2017; 13(10): 1047-62.

[121] Amsden GW, Whitaker AM, Johnson PW. Lack of bioequivalence of levofloxacin when coadministered with a mineral-fortified breakfast of juice and cereal. J Clin Pharmacol 2003; 43(9): 990-5.

[122] Wallace AW, Victory JM, Amsden GW. Lack of bioequivalence when levofloxacin and calcium-fortified orange juice are coadministered to healthy volunteers. J Clin Pharmacol 2003; 43(5): 53944.

[123] Neuhofel AL, Wilton JH, Victory JM, Hejmanowsk LG, Amsden GW. Lack of bioequivalence of ciprofloxacin when administered with calcium-fortified orange juice: A new twist on an old interaction. J Clin Pharmacol 2002; 42(4): 461-6.

[124] Aranceta Bartrina J, Arija Val VV, Maíz Aldalur E, et al. Dietary Guidelines for the Spanish population (SENC, diciembre 2016); the new graphic icon of healthy food. Nutr Hosp 2016; 33(Suppl. 8): 148.

[125] Hiller LD, Shaw RF, Fabri PJ. Difference in composite end point of readmission and death between malnourished and nonmalnourished veterans assessed using Academy of Nutrition and Dietetics/American Society for Parenteral and Enteral Nutrition Clinical Characteristics. JPEN J Parenter Enteral Nutr 2017; 41(8): 131624.

[126] Win AZ, Ceresa C, Arnold K, Allison TA. High prevalence of malnutrition among elderly veterans in home based primary care. J Nutr Health Aging 2017; 21(6): 610-3.

[127] O'Toole TP, Roberts CB, Johnson EE. Screening for food insecurity in six veterans administration clinics for the homeless, JuneDecember 2015. Prev Chronic Dis 2017; 14: E04

[128] Becerra MB, Hassija CM, Becerra BJ. Food insecurity is associated with unhealthy dietary practices among US veterans in California. Public Health Nutr 2017; 20(14): 2569-76.

[129] Miller DP, Larson MJ, Byrne T, DeVoe E. Food insecurity in veteran households: Findings from nationally representative data. Public Health Nutr 2016; 19(10): 1731-40.

[130] Ko LK, Allicok M, Campbell MK, et al. An examination of sociodemographic, health, psychological factors, and fruit and vegetable consumption among overweight and obese U.S. veterans. Mil Med 2011; 176(11): 1281-6.

[131] Park SY, Zhu K, Potter JF, Kolonel LN. Health-related characteristics and dietary intakes of male veterans and non-veterans in the Multiethnic Cohort Study (United States). J Mil Veterans Health 2011; 19(2): 4-9.
[132] Hoerster KD, Wilson S, Nelson KM, Reiber GE, Masheb RM. Diet quality is associated with mental health, social support, and neighborhood factors among Veterans. Eat Behav 2016; 23: 168-73.

[133] Tessier JM, Erickson ZD, Meyer HB, et al. Therapeutic lifestyle changes: Impact on weight, Quality of Life, and psychiatric symptoms in veterans with mental illness. Mil Med 2017; 182(9): e173844.

[134] Sai XY, He Y, Men K, et al. All-cause mortality and risk factors in a cohort of retired military male veterans, Xi'an, China: An 18-year follow up study. BMC Public Health 2007; 7: 290.

[135] Hoerster KD, Jakupcak M, Hanson R, et al. PTSD and depression symptoms are associated with binge eating among US Iraq and Afghanistan veterans. Eat Behav 2015; 17: 115-8.

[136] Johnsen GE, Asbjørnsen AE. Consistent impaired verbal memory in PTSD: A meta-analysis. J Affect Disord 2008; 111(1): 74-82.

[137] Vancampfort D, Rosenbaum S, Ward PB, et al. Type 2 diabetes among people with posttraumatic stress disorder: systematic review and meta-analysis. Psychosom Med 2016; 78(4): 465-73.

[138] Edmondson D, Kronish IM, Shaffer JA, Falzon L, Burg MM. Posttraumatic stress disorder and risk for coronary heart disease: A meta-analytic review. Am Heart J 2013; 166(5): 806-14.

[139] Rosenbaum S, Stubbs B, Ward PB, Steel Z, Lederman O, Vancampfort $\mathrm{D}$. The prevalence and risk of metabolic syndrome and its components among people with posttraumatic stress disorder: A systematic review and meta-analysis. Metabolism 2015; 64(8): 926-33.

[140] Tzamaloukas AH, Saddler MS, Murphy G, et al. Volume of distribution and fractional clearance of urea in amputees on continuous ambulatory peritoneal dialysis. Perit Dial Int 1994; 14(4): 356-61.

[141] Wilt TJ, Carlson KF, Goldish GD, et al. Carbohydrate and lipid disorders and relevant considerations in persons with spinal cord injury. Evid Rep Technol Assess (Full Rep) 2008; 163(163): 1-95.

[142] Kearney DJ, Milton ML, Malte CA, McDermott KA, Martinez M, Simpson TL. Participation in mindfulness-based stress reduction is not associated with reductions in emotional eating or uncontrolled eating. Nutr Res 2012; 32(6): 413-20.

[143] Erickson ZD, Kwan CL, Gelberg HA, et al. A randomized, controlled multisite study of behavioral interventions for veterans with mental illness and antipsychotic medication-associated obesity. J Gen Intern Med 2017; 32(Suppl. 1): 32-9.

[144] Goldberg RW, Reeves G, Tapscott S, et al. "MOVE!" Outcomes of a weight loss program modified for veterans with serious mental illness. Psychiatr Serv 2013; 64(8): 737-44.

[145] Harrold SA, Libet J, Pope C, Lauerer JA, Johnson E, Edlund BJ. Increasing physical activity for veterans in the Mental Health Intensive Case Management Program: A community-based intervention. Perspect Psychiatr Care 2018; 54(2): 266-73.

[146] Wu MK, Wang CK, Bai YM, Huang CY, Lee SD. Outcomes of obese, clozapine-treated inpatients with schizophrenia placed on a six-month diet and physical activity program. Psychiatr Serv 2007 58(4): 544-50.

147] Murata GH, Shah JH, Duckworth WC, Wendel CS, Mohler MJ, Hoffman RM. Food frequency questionnaire results correlate with metabolic control in insulin-treated veterans with type 2 diabetes: the Diabetes Outcomes in Veterans Study. J Am Diet Assoc 2004; 104(12): 1816-26.

[148] Miller MG, Thangthaeng N, Poulose SM, Shukitt-Hale B. Role of fruits, nuts, and vegetables in maintaining cognitive health. Exp Gerontol 2017; 94: 24-8.

[149] Nurk E, Refsum H, Drevon CA, et al. Cognitive performance among the elderly in relation to the intake of plant foods. The Hordaland Health Study. Br J Nutr 2010; 104(8): 1190-201.

[150] Yarla NS, Polito A, Peluso I. Effects of olive oil on TNF- $\alpha$ and IL6 in humans: Implication in obesity and frailty. Endocr Metab Immune Disord Drug Targets 2018; 18(1): 63-74.

[151] Diet, nutrition and the prevention of chronic diseases. World Health Organ Tech Rep Ser 2003; 916: i-viii, 1-149, backcover. [backcover.]

[152] Vitiello V, Germani A, Capuzzo Dolcetta E, Donini LM, Del Balzo $\mathrm{V}$. The new modern mediterranean diet italian pyramid. Ann Ig 2016; 28(3): 179-86.

[153] Navarro SL, Chen Y, Li L, et al. UGT1A6 and UGT2B15 polymorphisms and acetaminophen conjugation in response to a randomized, controlled diet of select fruits and vegetables. Drug Metab Dispos 2011;39(9): 1650-7. 
[154] Cuciureanu M, Vlase L, Muntean D, Varlan I, Cuciureanu R. Grapefruit juice--drug interactions: importance for pharmacotherapy. Rev Med Chir Soc Med Nat Iasi 2010; 114(3): 885-91.

[155] Bailey DG. Predicting clinical relevance of grapefruit-drug interactions: A complicated process. J Clin Pharm Ther 2017; 42(2): 125 7.

[156] Haber SL, Cauthon KA, Raney EC. Cranberry and warfarin interaction: A case report and review of the literature. Consult Pharm 2012; 27(1): 58-65.

[157] Komperda KE. Potential interaction between pomegranate juice and warfarin. Pharmacotherapy 2009; 29(8): 1002-6.

[158] Woodward CJ, Deyo ZM, Donahue KE, Deal AM, Hawes EM. Clinically relevant interaction between warfarin and scuppernongs, a quercetin containing muscadine grape: continued questions surrounding flavonoid-induced warfarin interactions. BMJ Case Rep 2014; 2014: bcr2013009608.

[159] Cambria-Kiely JA. Effect of soy milk on warfarin efficacy. Ann Pharmacother 2002; 36(12): 1893-6.

[160] Liu RH. Health-promoting components of fruits and vegetables in the diet. Adv Nutr 2013; 4(3): 384S-92S

[161] Hamirudin AH, Walton K, Charlton K, et al. Feasibility of homebased dietetic intervention to improve the nutritional status of older adults post-hospital discharge. Nutr Diet 2017; 74(3): 217-23.

[162] Heuberger R. Polypharmacy and food-drug interactions among older persons: A review. J Nutr Gerontol Geriatr 2012; 31(4): 325 403.

[163] McCabe BJ. Prevention of food-drug interactions with special emphasis on older adults. Curr Opin Clin Nutr Metab Care 2004; 7(1): 21-6.

[164] Shi Z, Yuan B, Taylor AW, et al. Riboflavin intake and 5-year blood pressure change in Chinese adults: interaction with hypertensive medication. Food Nutr Bull 2014; 35(1): 33-42.

[165] Greenblatt DJ, Harmatz JS, Singh NN, Roth T, Harris SC, Kapil RP. Influence of food on pharmacokinetics of zolpidem from fast dissolving sublingual zolpidem tartrate tablets. J Clin Pharmacol 2013; 53(11): 1194-8.

[166] Genser D. Food and drug interaction: consequences for the nutrition/health status. Ann Nutr Metab 2008; 52(Suppl. 1): 29-32.

[167] Rohde LE, de Assis MC, Rabelo ER. Dietary vitamin K intake and anticoagulation in elderly patients. Curr Opin Clin Nutr Metab Care 2007; 10(1): 1-5.

[168] Franco V, Polanczyk CA, Clausell N, Rohde LE. Role of dietary vitamin $\mathrm{K}$ intake in chronic oral anticoagulation: prospective evidence from observational and randomized protocols. Am J Med 2004; 116(10): 651-6

[169] Beatty SJ, Mehta BH, Rodis JL. Decreased warfarin effect after initiation of high-protein, low-carbohydrate diets. Ann Pharmacother 2005; 39(4): 744-7.

[170] Hornsby LB, Hester EK, Donaldson AR. Potential interaction between warfarin and high dietary protein intake. Pharmacotherapy 2008; 28(4): 536-9.

[171] Kokkinos P, Myers J, Faselis C, et al. Exercise capacity and mortality in older men: A 20-year follow-up study. Circulation 2010; 122(8): 790-7.

[172] Peterson MJ, Pieper CF, Sloane R, et al. Differences between completely physically inactive and low active older men and their response to an exercise intervention: the Veterans LIFE study. Healthy Aging Res 2015; 4: 36.

[173] Hall KS, Crowley GM, Bosworth HB, Howard TA, Morey MC. Individual progress toward self-selected goals among older adults enrolled in a physical activity counseling intervention. J Aging Phys Act 2010; 18(4): 439-50.

[174] Hall KS, Gregg J, Bosworth HB, et al. Physical activity counseling promotes physical and psychological resilience in older veterans with posttraumatic stress disorder. Ment Health Phys Act 2016; 11: 53-9.

[175] Peterson MJ, Williams N, Caves K, Morey MC. A pilot study of partial unweighted treadmill training in mobility-impaired older adults Biomed Res Int. ID 2014; p. 321048.

[176] Hall KS, Beckham JC, Bosworth HB, Sloane R, Pieper CF, Morey MC. PTSD is negatively associated with physical performance and physical function in older overweight military Veterans. J Rehabil Res Dev 2014; 51(2): 285-95.

[177] Faselis C, Doumas M, Pittaras A, et al. Exercise capacity and allcause mortality in male veterans with hypertension aged $\geq 70$ years. Hypertension 2014; 64(1): 30-5.
[178] Hastings SN, Sloane R, Morey MC, Pavon JM, Hoenig H. Assisted early mobility for hospitalized older veterans: preliminary data from the STRIDE program. J Am Geriatr Soc 2014; 62(11): 2180

[179] Morey MC, Ekelund C, Pearson M, et al. Project LIFE: A partnership to increase physical activity in elders with multiple chronic illnesses. J Aging Phys Act 2006; 14(3): 324-43.

[180] McAuley PA, Beavers KM. Contribution of cardiorespiratory fitness to the obesity paradox. Prog Cardiovasc Dis 2014; 56(4): 434 40.

[181] McAuley P, Myers J, Abella J, Froelicher V. Body mass, fitness and survival in veteran patients: Another obesity paradox? Am J Med 2007; 120(6): 518-24

[182] Littman AJ, McFarland LV, Thompson ML, et al. Weight loss intention, dietary behaviors, and barriers to dietary change in veterans with lower extremity amputations. Disabil Health J 2015; 8(3): 325-35.

[183] Chockalingam N, Thomas NB, Duval L. Should preparation for elite sporting participation be included in the rehabilitation process of war-injured veterans? Prosthet Orthot Int 2012; 36(3): 270-7.

[184] Baeza A, Paniagua J, Rufo M, Guillén J, Sterling A. Seasonal variations in radionuclide transfer in a Mediterranean grazing-land ecosystem. J Environ Radioact 2001; 55(3): 283-302.

[185] Glowacki J, LeBoff MS, Kolatkar NS, Thornhill TS, Harris MB. Importance of vitamin D in hospital-based fracture care pathways. J Nutr Health Aging 2008; 12(5): 291-3.

[186] Lansdown DA, Whitaker A, Wustrack R, Sawyer A, Hansen EN. A resident-led initiative improves screening and treatment for vitamin D deficiency in patients with hip fractures. Clin Orthop Relat Res 2017; 475(1): 264-70.

[187] Moniz C, Dew T, Dixon T. Prevalence of vitamin D inadequacy in osteoporotic hip fracture patients in London. Curr Med Res Opin 2005; 21(12): 1891-4

[188] Riley RL, Carnes ML, Gudmundsson A, Elliott ME. Outcomes and secondary prevention strategies for male hip fractures. Ann Pharmacother 2002; 36(1): 17-23.

[189] Akhigbe T, Chin AS, Svircev JN, et al. A retrospective review of lower extremity fracture care in patients with spinal cord injury. J Spinal Cord Med 2015; 38(1): 2-9.

Avenell A, Mak JC, O'Connell D. Vitamin D and vitamin D analogues for preventing fractures in post-menopausal women and older men. Cochrane Database Syst Rev 2014; 4(4): CD000227.

[191] Kojima G, Tamai A, Masaki K, et al. Prevalence of vitamin D deficiency and association with functional status in newly admitted male veteran nursing home residents. J Am Geriatr Soc 2013; 61(11): 1953-7.

[192] Gerber M. Hoffman R2.: The Mediterranean diet: health, science and society. Br J Nutr 2015; 113: 4-10.

[193] Shahar DR, Houston DK, Hue TF, et al. Adherence to mediterranean diet and decline in walking speed over 8 years in communitydwelling older adults. J Am Geriatr Soc 2012; 60(10): 1881-8.

[194] Talegawkar SA, Bandinelli S, Bandeen-Roche K, et al. A higher adherence to a Mediterranean-style diet is inversely associated with the development of frailty in community-dwelling elderly men and women. J Nutr 2012; 142(12): 2161-6.

[195] Kyrozis A, Psaltopoulou T, Stathopoulos P, Trichopoulos D, Vassilopoulos D, Trichopoulou A. Dietary lipids and geriatric depression scale score among elders: the EPIC-Greece cohort. J Psychiatr Res 2009; 43(8): 763-9.

[196] Yaffe K, Hoang TD, Byers AL, Barnes DE, Friedl KE. Lifestyle and health-related risk factors and risk of cognitive aging among older veterans. Alzheimers Dement 2014; 10(3)(Suppl.): S1 11-21.

[197] Yannakoulia M, Kontogianni M, Scarmeas N. Cognitive health and Mediterranean diet: Just diet or lifestyle pattern? Ageing Res Rev 2015; 20: 74-8

[198] Dominguez LJ, Barbagallo M. The relevance of nutrition for the concept of cognitive frailty. Curr Opin Clin Nutr Metab Care 2017; 20(1): $61-8$

[199] Hernández-Galiot A, Goñi I. Adherence to the Mediterranean diet pattern, cognitive status and depressive symptoms in an elderly non-institutionalized population. Nutr Hosp 2017; 34(2): 338-44.

[200] Valls-Pedret C, Sala-Vila A, Serra-Mir M, et al. mediterranean diet and age-related cognitive decline: A randomized clinical trial JAMA Intern Med 2015; 175(7): 1094-103. 
[201] Skarupski KA, Tangney CC, Li H, Evans DA, Morris MC. Mediterranean diet and depressive symptoms among older adults over time. J Nutr Health Aging 2013; 17(5): 441-5.

[202] Altamirano Martínez MB, Cordero Muñoz AY, Macedo Ojeda G, Márquez Sandoval YF, Vizmanos B. A review of graphical representations used in the dietary guidelines of selected countries in the americas, europe and asia. Nutr Hosp 2015; 32(3): 986-96.

[203] Montagnese C, Santarpia L, Buonifacio M, et al. European foodbased dietary guidelines: A comparison and update. Nutrition 2015; 31(7-8): 908-15.

[204] Gil A, Ruiz-Lopez MD, Fernandez-Gonzalez M, Martinez de Victoria E. The FINUT healthy lifestyles guide: Beyond the food pyramid. Adv Nutr 2014; 5(3): 358S-67S.

[205] Ruini LF, Ciati R, Pratesi CA, Marino M, Principato L, Vannuzzi E. Working toward healthy and sustainable diets: The "Double Pyramid Model" developed by the barilla center for food and nutrition to raise awareness about the environmental and nutritional impact of foods. Front Nutr 2015; 2: 9.

[206] Ko HJ, Youn CH, Kim SH, Kim SY. Effect of pet insects on the psychological health of community-dwelling elderly people: A single-blinded, randomized, controlled trial. Gerontology 2016; 62(2): 200-9.

[207] Hsu TJ, Tsai HT, Hwang AC, Chen LY, Chen LK. Predictors of non-pharmacological intervention effect on cognitive function and behavioral and psychological symptoms of older people with dementia. Geriatr Gerontol Int 2017; 17(Suppl. 1): 28-35.

[208] Bach-Faig A, Berry EM, Lairon D, et al. Mediterranean diet pyramid today. Science and cultural updates. Public Health Nutr 2011; 14(12A): 2274-84.

[209] Fara GM. Nutrition between sustainability and quality. Ann Ig 2015; 27(5): 693-704.

[210] Gil Á, Martinez de Victoria E, Olza J. Indicators for the evaluation of diet quality. Nutr Hosp 2015; 31(Suppl. 3): 128-44.

[211] LaVela SL, Etingen B, Miskevics S. Factors influencing self-care behaviors in persons with spinal cord injuries and disorders. Top Spinal Cord Inj Rehabil 2016; 22(1): 27-38.

[212] Dausch BM, Saliman S. Use of family focused therapy in rehabilitation for veterans with traumatic brain injury. Rehabil Psychol 2009; 54(3): 279-87.

[213] Teo AR, Marsh HE, Forsberg CW, et al. Loneliness is closely associated with depression outcomes and suicidal ideation among military veterans in primary care. J Affect Disord 2018; 230: 42-9.

[214] Utzon-Frank N, Breinegaard N, Bertelsen M, et al. Occurrence of delayed-onset post-traumatic stress disorder: A systematic review and meta-analysis of prospective studies. Scand J Work Environ Health $2014 ; 40(3): 215-29$

[215] Wright BK, Kelsall HL, Sim MR, Clarke DM, Creamer MC. Support mechanisms and vulnerabilities in relation to PTSD in veterans of the Gulf War, Iraq War, and Afghanistan deployments: A systematic review. J Trauma Stress 2013; 26(3): 310-8.

[216] Sachs-Ericsson N, Joiner TE, Cougle JR, Stanley IH, Sheffler JL. Combat exposure in early adulthood interacts with recent stressors to predict PTSD in aging male veterans. Gerontologist 2016; 56(1) 82-91.

[217] Davison EH, Kaiser AP, Spiro A III, Moye J, King LA, King DW. From Late-Onset Stress Symptomatology to Later-Adulthood Trauma Reengagement in Aging Combat Veterans: Taking a Broader View. Gerontologist 2016; 56(1): 14-21.

[218] King LA, King DW, Vickers K, Davison EH, Spiro A III. Assessing late-onset stress symptomatology among aging male combat veterans. Aging Ment Health 2007; 11(2): 175-91.

[219] Peluso I, Palmery M. Flavonoids at the pharma-nutrition interface: Is a therapeutic index in demand? Biomed Pharmacother 2015; 71 102-7.

[220] Samant SS, Wilkes K, Odek Z, Seo HS. Tea-induced calmness: Sugar-sweetened tea calms consumers exposed to acute stressor. Sci Rep 2016; 6: 36537.

[221] Macht M, Mueller J. Immediate effects of chocolate on experimentally induced mood states. Appetite 2007; 49(3): 667-74

[222] DiNapoli EA, Cinna C, Whiteman KL, Fox L, Appelt CJ, Kasckow J. Mental health treatment preferences and challenges of living with multimorbidity from the veteran perspective. Int J Geriatr Psychiatry 2016; 31(10): 1097-104

[223] Köberlein J, Gottschall M, Czarnecki K, Thomas A, Bergmann A Voigt K. General practitioners' views on polypharmacy and its consequences for patient health care. BMC Fam Pract 2013; 14: 119.

[224] Rollason V, Vogt N. Reduction of polypharmacy in the elderly: A systematic review of the role of the pharmacist. Drugs Aging 2003; 20(11): 817-32.

[225] Hanlon JT, Semla TP, Schmader KE. Medication misadventures in older adults: literature from 2013. J Am Geriatr Soc 2014; b62: 1950-3.

[226] Akamine D, Filho MK, Peres CM. Drug-nutrient interactions in elderly people. Curr Opin Clin Nutr Metab Care 2007; 10(3): 304 10 . 